ACTA VET. BRNO, 56, 1987: $475-486$

\title{
INCIDENCE OF TOXOPLASMA GONDII ANTIBODIES IN DOGS FROM BRNO AND ITS ENVIRONS
}

M. SVOBODA

Department of Diagnostics, Therapy and Control of Animal Diseases, University of Veterinary Science, 61242 Brno

Received December 12, 1986

A bstract

$S$ v o b o d a M .: Incidence of Toxoplasma gondii Antibodies in Dogs from Brno and Its Environs. Acta vet. Brno, 56, 1987: 475-486.

A total of 1002 dogs of various ages were examined for the incidence of Toxoplasma gondi antibodies during a 3 -year period. The serological examinations were carried out with the Sabin-Feldman reaction (SFR), complement-fixation test (CFT) and microprecipitation in agar gel (MPA) according to standard procedures valid in Czechoslovakia. Examination with SFR demonstrated T. gondi antibodies in 325 ( $32.4 \times$ ) dogs in titres of 4 to 64 . Examination with CFT revealed specific antibodies in 358 ( 35.7 \%) animals in titres of 5 to 80 . In the dilution of $1: 5,266(26.6 \%)$ dog sera were positive and $75(7.5 \%)$ sera were anticomplementary. MPA revealed $M$. gondi $i$ antibodies in $12(1.2 \%)$ dogs.

With one of the three methods $T$. gondi $i$ antibodies were demonstrated in $309(30.8 \mathrm{x})$ dogs. The coincidence of two serological reactions was found in $186(18.6 \%)$ dogs and the coincidence of all three.serological reactions was recorded in $6(0.6 \%)$ animals. In a total of $501(50.0 \%)$ dogs positive results were obtained with 1 to 3 of the methods, i.e. half of the dogs yielded positive results with at least one of the three methods.

The diagnostic value of the three methods of which SFR proved to be the most useful is discussed.

Dog, toxoplasmosis, serological diagnosis, antibody, Sabin-feldman reaction (SFR), complement-fixation test (CFT), microprecipitation in agar gel (MPA).

Toxoplasmosis has been given considerable attention in recent years. Although the role of the dog in its spread has generally been regarded as one of little significance, the close contact of the dog with man has prompted rather numerous investigations and screening schemes in this respect in various parts of the world. Our study was designed to assess the incidence of Toxoplasma gondii antibodies in dogs coming from Brno and its environs and evaluate serological methods used for the diagnosis of toxoplasmosis in the dog. 
Published data on the results of serological screening are summarized in Table 1 . It can be seen that the proportion of dogs with $T$. gondii antibodies in various countries ranged from $5.3 \%$ to $57.5 \%$, mostly depending on the method of examination.

A very sensitive and specific method that is suitable also for examination of animals is the Sabin-Feldman reaction (SFR) ( $k$ a t s ube et al. 1972). Another relatively sensitive and well-reproducible method is the complement-fixation test (CFT) which is suitable for detection of active infection (D y m ow s a 1972). It detects antibodies a few days later than SFR (on the 12 th day at the earliest) and the curve of antibody development with this test shows slightly lower values than is the case with SFR. A disadvantage in some animal species is frequent occurrence of anticomplementarity of the sera ( $\mathrm{j}$ i a and $R$ o s icky 1983). Microprecipitation in agar gel (MPA) is based on the prineiple of double radial immunodiffusion. Hübner and Uhliková (1973) regard MPA as indicator of "non-sterile immunity". In their view, positive MPA indicates the presence of $T$. gondii in the body and is suitable for detection of animal reservoirs. However, it is as late as the 5 th week after penetration of $T$. gondii into the body that antibodies can be detected with this method. On the other hand, $\mathrm{Kouba}$ et al. (1974) and other investigators ( $J i r a$ and Rosickj 1983) found MPA less sensitive and demonstrated that its negative result did not exclude the presence of toxoplasmosis.

\section{Materials and Methods}

A total of 1002 dogs were examined for $T$. gondii antibodies in the years 1981 to 1984 . More than $76 \%$ of them were animals either treated at the out-patient department of the small animal disease clinic of the University of Veterinary Science, Brno, or hospitalized in the clinic. The remaining dogs were clinically healthy animals examined for toxoplasmosis within a prevention program. On the whole, the sample included 641 male and 361 female dos of 58 breeds (and crossbreds), 3 weeks to 20 years of age and 2 to $62 \mathrm{~kg}$ in body mass. Most of the animals were police dogs, mainly German sheep-dogs.

Blood samples ( 2 to $10 \mathrm{ml}$ in volume) were obtained from the vena cephalica antebrachii or the vena saphena. In indicated cases serological examinations were repeated twice to six times to assess the dynamics of antibody titres. The blood samples were incubated for 2 hours at $37^{\circ} \mathrm{C}$ and then centrifuged at $300 \mathrm{~g}$ for 2 minutes. The sera were stored in stoppered glass test-tubes at $-20{ }^{\circ} C$ until examination.

Serological examinations were carried out by means of three methods: SRF, CFT and MPA. Series of usually 30 sera were examined concurrently at 14 -day intervals. The sera were inactivated in water bath at $56^{\circ} \mathrm{C}$ for 30 minutes.

SFR was carried out according to the standard laboratory method of the Central State Veterinary Institute, Prague. The titre was expressed as the reciprocal value of the highest serum dilution

\footnotetext{
+5erological examinations were carried out in the Department Epizootiology and Microbiology of the University of Veterinary Science, Brno.
} 
Table 1

Incidence of Toxoplasma gondii antibodies in dogs as reported in the literature

\begin{tabular}{|c|c|c|c|c|c|c|c|}
\hline Year & Authors & Country & Test & $\begin{array}{l}\text { No. dogs } \\
\text { exa- } \\
\text { mined }\end{array}$ & $\begin{array}{l}\text { Pos } \\
\text { fint } \\
\text { No. }\end{array}$ & $\begin{array}{l}\text { tive } \\
\text { ings } \\
\%\end{array}$ & $\begin{array}{l}\text { Titre re- } \\
\text { garded as } \\
\text { positive }\end{array}$ \\
\hline $\begin{array}{l}1958 \\
1966 \\
1973 \\
1974 \\
1977 \\
1977 \\
1977 \\
1977\end{array}$ & $\begin{array}{l}\text { Havlík and Hübner } \\
\text { Zástěra et al. } \\
\text { Kovaleva and Lavočkin } \\
\text { Catár } \\
\text { Hagiwara } \\
\text { Hagiwara } \\
\text { Martin et al. } \\
\text { Sibalič }\end{array}$ & $\begin{array}{l}\text { ČSSR } \\
\text { ČSSR } \\
\text { USSR } \\
\text { ČSSR } \\
\text { Japan } \\
\text { Japan } \\
\text { Canada } \\
\text { Yugo- }\end{array}$ & $\begin{array}{l}\text { SFR } \\
\text { SFR } \\
\text { CFT } \\
\text { CFT } \\
\text { SFR } \\
\text { DH } \\
\text { DH } \\
\text { CFT }\end{array}$ & $\begin{array}{r}86 \\
201 \\
- \\
24 \\
911 \\
607 \\
137 \\
-\end{array}$ & $\begin{array}{r}27 \\
109 \\
- \\
6 \\
264 \\
159 \\
17 \\
-\end{array}$ & $\begin{array}{l}31.3 \\
54.2 \\
24.6 \\
25.0 \\
29.0 \\
26.2 \\
13.1 \\
41.0\end{array}$ & 64 and higher \\
\hline $\begin{array}{l}1978 \\
1978 \\
1978 \\
1979 \\
1979 \\
1979 \\
1979 \\
1980 \\
1982 \\
1982 \\
1982\end{array}$ & $\begin{array}{l}\text { Ogunrinade } \\
\text { Sedaghat et al. } \\
\text { Riemann et al. } \\
\text { Böhm } \\
\text { Chhabra and Mahajan } \\
\text { Sacco et al. } \\
\text { Sacco et al. } \\
\text { Puccini and Abbenante } \\
\text { Vokoun } \\
\text { Vokoun } \\
\text { Watson et al. }\end{array}$ & $\begin{array}{l}\text { Nigeria } \\
\text { Iran } \\
\text { USA } \\
\text { GFR } \\
\text { India } \\
\text { Italy } \\
\text { Italy } \\
\text { Italy } \\
\text { ČSSR } \\
\text { CSSR } \\
\text { Austra- }\end{array}$ & $\begin{array}{l}\text { SFR } \\
\text { IF } \\
\text { IH } \\
\text { IH } \\
\text { IH } \\
\text { IF } \\
\text { DH } \\
\text { IF } \\
\text { MPA } \\
\text { CFT } \\
\text { DH }\end{array}$ & $\begin{array}{r}40 \\
118 \\
804 \\
500 \\
119 \\
82 \\
94 \\
355 \\
549 \\
346 \\
129\end{array}$ & $\begin{array}{r}23 \\
27 \\
112 \\
142 \\
35 \\
29 \\
38 \\
179 \\
42 \\
198 \\
40\end{array}$ & $\begin{array}{l}57.5 \\
22.9 \\
13.9 \\
28.4 \\
29.4 \\
35.2 \\
40.4 \\
50.4 \\
7.6 \\
57.2 \\
31.0\end{array}$ & $\begin{array}{r}8 \text { and higher } \\
64 \text { and higher }\end{array}$ \\
\hline $\begin{array}{l}1983 \\
1985 \\
1985\end{array}$ & $\begin{array}{l}\text { Ahmed et al. } \\
\text { Sebek } \\
\text { Sebek }\end{array}$ & $\begin{array}{l}\text { USA } \\
\text { ČSSR } \\
\text { ČSSR }\end{array}$ & $\begin{array}{l}\text { IF } \\
\text { SFR } \\
\text { CFT }\end{array}$ & $\begin{array}{l}448 \\
301 \\
301\end{array}$ & $\begin{array}{l}59 \\
16 \\
23\end{array}$ & $\begin{array}{r}13.2 \\
5.3 \\
7.6\end{array}$ & $\begin{array}{r}64 \text { and higher } \\
4 \text { and higher } \\
10 \text { and higher }\end{array}$ \\
\hline
\end{tabular}

IF = indirect fluorescence test

IH = indirect haemagglutination test

$\mathrm{DH}=$ direct haemagglutination test

at which more than $50 \%$ of tachyzoites that had been added to the serum remained unstained with methylene blue and retained their typical shape. Titres of 4 and higher were regarded as positive.

CFT was carried out according to standard procedures approved by the Ministry of Agriculture using biologicals produced by the Institute of Sera and Vaccines, Prague. The test was started at the initial dilution of $1: 5$. Sera with distinct agglutination were diluted in twofold steps. Titres of 5 and higher were regarded as positive.

MPA was carried out according to the official method of the Institute of Sera and Vaccines, Prague, using commercial diagnostic kits (Sevatest toxoplasma test MPA). A distinct precipitation line in gel between the test serum and commercial antigen was regarded as positive reaction. 
The results of serological examination in 1002 dogs are presented graphically in Fig. 1 .

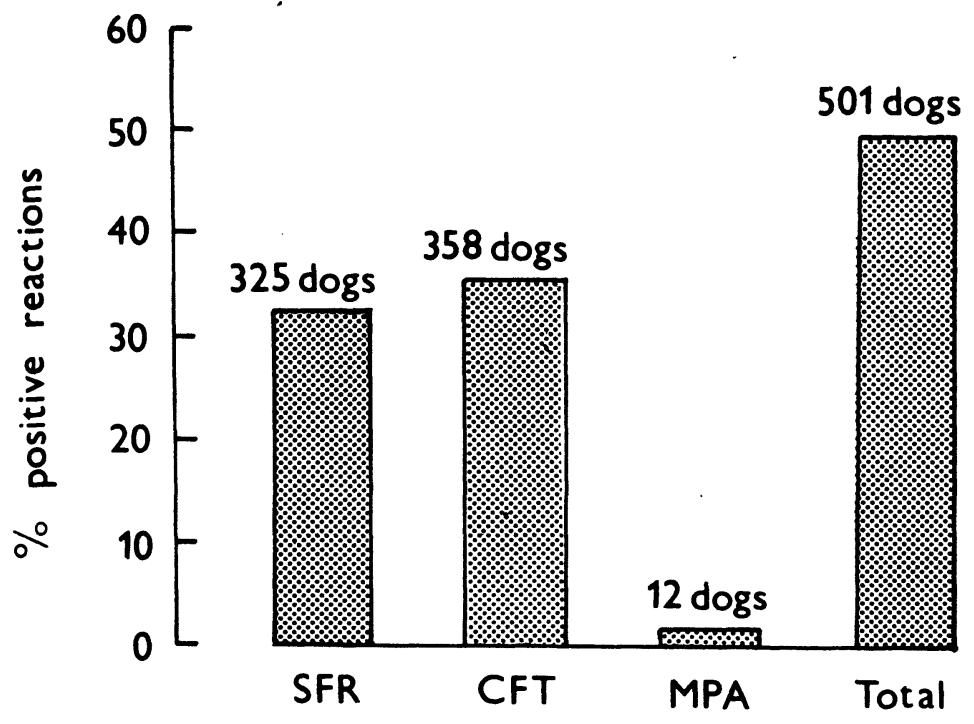

Fig. 1. Results of serological reactions

SFR revealed $T$. gondii antibodies in 325 ( $32.44 \%$ ) dogs in titres of 4 to 64 . Most of the sera (21.96\%) were positive in the basic dilution of $1: 4$. The titre of 64 was found in only one dog. The results according to antibody titres are summarized in Table 2 .

The results obtained with CFT are shown in Table 1 . At the serum dilutions of $1: 5$ to $1: 80$ positive reaction was found in 358 $(38.73 \%)$ dogs. At the basic titre of 5 the proportion of posi-. tive dogs was $26.55 \%$, the titre of 80 was found in 2 dogs. The sera of $75(7.48 \%)$ dogs were anticomplementary.

MPA yielded positive results in 12 dogs, i.e. in $1.20 \%$ out of the animals examined.

Comparison of the results obtained with the three methods are shown in Table 4. Exactly one half of the dogs showed at least one positive reaction. The number of dogs in which T. gondii antibodies were detected with only one of the three methods was 309 $(30.84 \%)$. In $186(18.56 \%)$ dogs specific antibodies were revealed with two methods (SFR in combination with either CFT of MPA). In $6(0.60 \%)$ dogs $T$. gondii antibodies were detected with all three serological methods. It can also be seen in Table 4 that the most frequent combination of two methods yielding positive results was SFR and CFT (in $17.96 \%$ of the animals). On the other hand, some possible combinations of the results (e.g. positive MPA, the other two reactions negative) were not recorded at all. 
Table 2

Results obtained with the Sabin-Feldman reaction

\begin{tabular}{|c|c|c|}
\hline Sabin-Feldman reaction & No. dogs & $\%$ \\
\hline Negative & 677 & 67.56 \\
\hline $\begin{aligned} & \text { Positive } \text { - titre } 4 \\
& \text { - titre } 8 \\
& \text { - titre } 16 \\
& \text { - titre } 32 \\
& \text { - titre } 64\end{aligned}$ & $\begin{array}{r}220 \\
55 \\
35 \\
14 \\
1\end{array}$ & $\begin{array}{r}21.96 \\
5.49 \\
3.49 \\
1.40 \\
0.10\end{array}$ \\
\hline Total positive & 325 & 32.44 \\
\hline$T \circ t$ a 1 & 1002 & 100.00 \\
\hline
\end{tabular}

Table 3

Results obtained with the complement-fixation test

\begin{tabular}{lrr}
\hline Complement-fixation test & No. dogs & $\%$ \\
\hline Negative & 644 & 64.27 \\
Positive - titre 5 & 266 & 26.55 \\
- titre 10 & 43 & 4.29 \\
- titre 20 & 24 & 2.39 \\
- titre 40 & 23 & 2.30 \\
- titre 80 & 2 & 0.20 \\
\hline Total positive & 358 & 35.73 \\
\hline Tota l & 1002 & 100.00 \\
\hline
\end{tabular}

Discussion

In our study, SFR revealed $T$. gondi $i$ antibodies in almost every third dog and yet these findings are at the lower limit of the data reported by other writers. The surprisingly low incidence of $T$. gondi antibodies fourid by $S$ e be $k$ (1985) in police dogs of the Ministry of the Interior of the Czechoslovak Socialist Republic can be accounted for partly by rigid sanitation but in the first place by the use of commercial diets (Vetamix and Vetacan). It should also be pointed out that the proportions of animals with $T$. gondii antibodies as are reported in the literature are also dependent on the fact which titre was regarded as positive. In dogs, $T$. gondii antibody titres have generally been found 
Table 4

Comparison of the results obtained with MPA, CFT and SFR

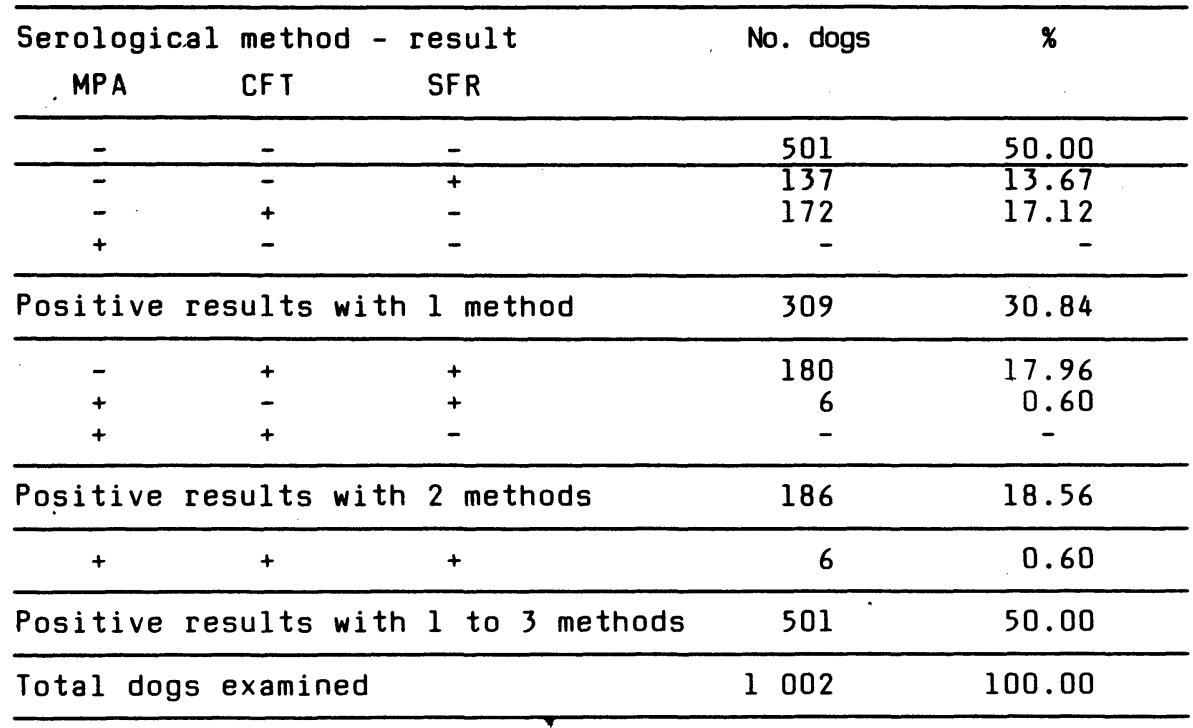

lower than those reportéd, e.g., for man, rabbits and laboratory mice. In most studies the basic dilutions of $1: 2,1: 4$ or $1: 10$ were regarded as positive ( $D$ u bey 1973; Hejlič ek et al.

$1981 ; H$ a $y$ et al. 1983). This approach is supported by positive $T$. gondii isolations from animals having only the basic titres of specific antibodies. Also in our study $T$. gondii antibody $t i-$ tres were relatively low: titres of 16 and higher were found in only less than $5 \%$ of the dogs. Low $T$. gondii antibody titres in naturally infected dogs are presumably related to lower virulence of the causative strains, lower quantities of tissue cysts or possibly oocysts and tachyzoites that have produced the natural infection and to the short interval elapsing from the time of infection. Gther factors to be considered are natural mechanisms of devitalization of $T$. gondii cysts, depending on species-specific resistance of the animals. High T. gondii antibody titres ( 256 and higher), on the other hand, have been demonstrated in animals infected experimentally with highly virulent T. gondii strains ( $P$ iekarski and Whitte 197l; Frenkel 1982).

Since serum antibody levels are also known to decrease in consequence of careless handling of the sera (e.g. fluctuation in temperature) or their long-term storage, the sera in our study were stored for only such a length of time that was required to avoid waste of commercial kits (MPA, CFT) and chemicals. The frozen sera were stored generally for 14 days and only exceptionally for a few additional days. Whenever feasible, each test serum was examined with the three serological methods at one thawing. 
When examined with CFI, the sera of a relatively large proportion of the dogs in our study $(35.7 \%)$ were positive, but most of them showed $T$. gondii antibodies only in the basic dilution. Titres of 10 and higher, which were found with this method in less than $10 \%$ of the dogs, are, in our view, a more objective indicator as they showed far more coincidence with the results obtained with SFR.

Although inactivated at $56^{\circ} \mathrm{C}$ in water bath for 30 minutes prior to examination, the sera of 75 ( $7.5 \%$ ) dogs proved anticomplementary. The phenomenon of anticomplementarity of sera of some animal species has been highligted by Jira and Rosicky (1983). The anticomplementarity of the sera in our study was a problem and may have partly influenced the reading of the results, particularly at the basic dilution. According to pet te r se n (1968) the anticomplementarity of sera is due to a substance in antigen interfering with the results of titration and he suggested a chemical procedure by which the efficiency of antigen could be enhanced. S i i m (1984) recommended to inactivate sera at $58{ }^{\circ} \mathrm{C}$ for as long as 60 minutes before examination with CFT. In our study this prolonged inactivation was not tested.

If we regarded a positive outcome of MPA as indicator of "non-sterile immunity" (Hübner and Uhlikova 1973), it would mean that about 1 \% of dogs in our study could be classified as a reservoir of toxoplasmosis. According to $\mathrm{S}$ i $\mathrm{im}$ (1984) and Pet $\mathrm{tersen}(1984)$, on the other hand, a better indicator of the presence of $T$. gondii in the body is to be seen in the demonstration of antibodies with SFR.

A combination of three serological methods enables us to obtain 8 possible variants of the results, ranging from all negative to all positive. When the dynamics of antibody titres is taken into consideration, the combinations of theoretically possible results of the seroreactions increase by geometrical progression. The diagnostic value of each test is given by its specificity and sensitivity. The specificity of SFR and CFT has been demonstrated by a number of investigators ( $P i e k$ a $r k i$ and $W h$ t te 1971; $R$ a S I $n$ 1973; a.o.). SFR has been claimed to detect mainly IgG, whereas CFT is known to demonstrate mainly IgM. MPA is a reaction of substantially lower sensitivity: it yields positive results only where antibodies are present in large quantities.

In our study the proportion of dogs with $T$. gondii antibodies detected only with SFR was $13.7 \%$. In this group of animals two possibilities should be considered:

1/ The infection is of recent date, with only 2 to 4 weeks elapsing after the entry of $T$. gondii into. the body. Specific antibodies are demonstrated by highly sensitive SFR as early as the 9 th day after infection ( $K 0 . u b$ a et al. 1974) but are not detected by CFT and MPA because of their lower sensitivity and later onset of antibody production (the discrepancy is due to the methods and the dynamics of antibody production). Included in this group can also be the case of acute toxoplasmosis in a dog with specific antibodies detected in the 1:8 dilution only with SFR.

2/ The infection is of long standing - usually more than 6 months old, referred to as chronic toxoplasmosis, or the animal experienced contact with $T$. gondii in the past (latent infection). In this case the discrepancy is due to the dynamics of antibo- 
dy production (specific IgM is not present in the body and therefore CFT is negative) and to the methods (lower sensitivity of MPA).

To differentiate recent infection from that of long standing should not be difficult provided that serological examination is repeated 2 to 3 weeks later ( P r z y b y l ki ewic z 1972; Pouska 1977). Recent infections were generally characterized by a rise in antibody level.

More difficult to interpret are the results where antibodies are demonstrated only with CFT. According to $S$ i im (1984) few, if any, such results are likely to occur. Here, again, two possibilities should be taken into consideration:

1/ The infection is active, between 1 and 6 months old, during which time IgM is demonstrated, whereas the production of IgG, which is detected particularly with SFR, is reduced or halted for one reason or another. (The discrepancy is due to the dynamics of antibody production.) Some support is given to this view by the observation that this combination of results was found mostly in dogs with chronic or recurrent disease where immunosuppression seems possible as a result of treatment with corticosteroids or cytostatic agents or as a consequence of a concurrent major disease (parvovirosis, canine distemper, leptospirosis, etc.). In only quite exceptional cases complete immunotolerance can develop. Thus Presthus et al. (1982) demonstrated toxoplasmosis post mortem in 6 puppies, between 3 and 6 months of age, with signs of paresis of the hind legs. In none of them were T. gondii antibodies demonstrated with SFR.

2/ In the group of dogs where only CFT was positive, mainly in the basic dilution of $1: 5$, consideration should also be given to the possibility of erroneous reading of the results because of partial anticomplementarity of the sera.

Specific antibodies demonstrated concurrently with SFR and CFT were recorded in $18 \%$ of the dogs. In interpreting these results two possibilities, again, come into consideration:

1/ Where T. gondi $i$ antibodies were demonstrated with both SFR and CFT (qualitative coincidence) at titres higher at least by two dilutions than the basic titre (quantitative coincidence) it can be inferred that either active infection or reinfection between 3 and 6 weeks after the entry of T. gondii into the body was present. MPA is negative in consequence of later onset of precipitating antibodies (the discrepancy is due to the dynamics of antibody production) ( $\mathrm{I} r \mathrm{r}$ and $R$ o s i cky 1983; S i i m 1984). These findings indicate acute to subacute toxoplasmosis where the severity of the process is to be judged by the incidence and intensity of clinical signs.

$2 /$ Where specific antibodies were demonstrated with both SFR and CFT but only at the basic and low titres (low-level qualitative and quantitative coincidence), presumably subacute to chronic infection between 6 weeks and 6 months old was involved, MPA being negative during this period because of its lower sensitivity (discrepancy due to the method).

of particular interest from the aetiological point of view is the group of 6 dogs where specific antibodies were demonstrated concurrently with SFR and MPA. Precipitating antibodies were demonstrated concurrently with the higher titres (16 and higher) recoried with SFR. All the dogs involved were between 9 months 
and 2 years of age. A possible explanation of these findings is primary infection with a major dose of $T$. gondii (a rather virulent strain) in the state of transition to chronicity. Presumably a substantial degree of immunity had been produced and persisted in the form of IgG at a level so high that even the result of less sensitive MPA was positive (qualitative coincidence). Since IgM had disappeared from the body,. CFT yielded negative results.

In all 6 dogs in which $T$. gondi $i$ antibodies were demonstrated with all three serological methods toxoplasmosis was diagnosed on the basis of repeated examinations. The animals were in various stages of infection. In the light of the foregoing considerations it appears likely that the infection was rather severe, being produced by a strain of medium virulence 1 to 6 months ago.

It can be cóncluded that intravital diagnosis of toxoplasmosis in the dog will continue to be based on serological methods. The present study suggests that a combination of several serological methods. The present study suggests that a combination of several serological methods of various sensitivity thresholds that detect different immunoglobulins makes it possible to differentiate between active and chronic $T$. gondii infection provided that the dynamics of antibody levels is taken into account. Examinations should be repeated 2 to 3 weeks apart. Of the serological methods used in the present study, SFR can be fully recommended for examination of the dog. In using MPA, a positive result can be interpreted as indicating a severe process, whereas a negative result should be taken with reserve because the possibility of.T. gondii infection cannot be excluded. The use of CFT is limited by frequent occurrence of anticomplementarity in dog sera. Where use of this test is made in spite of this drawback, our recommendation is that only titres of 10 and higher should be regarded as positive.

\section{Vyskyt protilatek proti Toxoplasma gondii u psúz Brna a okoli}

$V$ prúběhu trú let byli vyšetreni 1002 psi vsech věkových kategorií se zaměrenim na výskyt protilátek proti Toxoplasma gondii. Sérologická šetrení byla prováděna Sabin-Feldmanovou reakci (SFR), komplementfixačni reakcí (KFR) a mikroprecipitaci $v$ agarovém gelu (MPA) dle metodik.platných v ČSSR. Sabin-Feldmanovou reakcí bylo v titru 4 - 64 pozitivnich 325 ( 32,4 \%) psú. Komplementfixační reakci byly prokázány protilátky v titru 5 - 80 u 358 $(35,7 \%)$ zviłat. V redění $1: 5$ bylo pozitivních $266(26,6 \%)$ psú a séra 75 psú $(7,5 \%)$ byla antikomplementárni. Mikroprecipitací $\checkmark$ agarovém gelu byly zjistěny pozitivní nálezy u 12 psú $(1,2 \%)$.

Jednou séroreakci byly zjištěny protilátky proti Toxoplasma gondi u 309 (30,8 \%) psú, koincidence dvou séroreakcl se vyskytla u $186(18,6 \%)$ zviłat a koincidence vsech tí séroreakci byla prokázána u $6(0,6 \%)$ psủ. Minimálně jednou séroreakcí (to znamená 1 až 3 pozitivni nálezy) byly zjištěny specifické protilátky u 501 psa $(50,0 \%)$.

$\checkmark$ práci je diskutována diagnostická hodnota použiých vyšetrovacich metod. Nejlépe se osvědčila Sabin-Feldmanova reakce. 


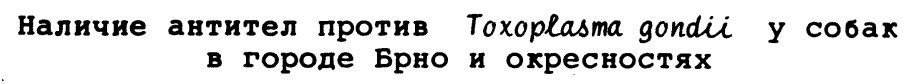

В течение трех лет исследовали 1002 собаки всех возрастных хатегории, направляя внимание на наличие антител против Toxoplasma gondii. Серологические анализы проводили реакцией по СабинФельдману (SFR), реакцией фихсации хомплемента (KFR) и микропреципитацией в агаровом геле (MPA) по методихам, действенным в чССР. Реакиией Сабин-Фельдмана было в титре 4 - 64 позитивных $325(32,48)$ спбах. Реахлиеи фихсации хомплемента были установлены антитела в титре $5-80$ у $358(35,78)$ животных. В разбавлении 1 : 5 было позитивных $266(26,68)$ собах и сыворотки 75 собах $(7,58)$ были антикомплементарны. Михропреципитацией в агаровом геле позитивные результаты были установлены у 12 собах $(1,28)$. Одной серореахиией были установлены антитела против Тохоplasma gondii у $309(30,88)$ собах, совпадение двух серореакцин встречалось у $186(18,68)$ животных и совпадение всех трех серореакций - у $6(0,68)$ собах. Не менее одной серореакцией (т.е. 1 - 3 позитивных анализа) были установлены специфические антитела. у 501 собаки $(50,08)$.

В работе обсуждается диагностическое значение применимых методов исследования. Лучше всех зарехомендовала себя реахция Сабин-Фельдмана.

\section{Acknowledgements}

I wish to thank Prof. MVDr. K. Hejliček, DrSc., head of the Department of Epizootiology and Microbiology of the University of Veterinary Science, Brno, for helpful suggestions and for enabling me to carry out the serological examinations in his specialized laboratory. Thanks are also extended to Mrs. M. Čržková for skilbul laboratory assistance.

\section{References}

AHMED, B. A. - GAAFAR, S. M. - WEIRICH, W. E. - KANITZ, C. L.: Relationship of Toxoplasma infections to other diseases in dogs. Veterinary Parasitology, 12, 1983: 199-203.

BUHM, A.: Untersuchungen über das Vorkommen von Kokzidien, (5arcocystis, Isospora, Hammondia, Toxoplasma) bei Hunden in Süddeutschland. (Inaugural Dissertation.) München 1979. 26 p. Ludwig-Maximilians Universität.

ČATÁ, G.: Toxoplazmóza v ekológických podmienkach na Slovensku. Veda - vydavatelstvo SAV Bratislava, 20, 1974: 5-136.

DUBEY, J. P.: Feline Toxoplasmosis and Coccidiosis: A Survey of Domiciled and Stray Cats. J. Amer. veter. med. Assoc., 162, 1973: 873-877.

DYMOWSKA, Z.: Ocena metod immunodiagnostycznych stosowanych $w$ rozpoznawaniu toksoplazmozy. Wiad. parazyt., 18, 1972: 187-192.

FRENKEL, J. K.: Common questions on toxoplasmosis: Veterinary,. medical, and public health considerations. Veter. Med. Small anim. Ciin., 77, 1982: 1188-1196. 
HAGIWARA, T.: Toxoplasmosis of animals in Japan. Int. J. Zoon., $4,1977: 56-70$.

HAV̆LIK, 0. - HUBNER, J.: Sérologický prủkaz toxoplazmy u některých domácích i volně žijícich zvírat. Čskoslov. Epidem. Mikrobiol. Imunobiol., 7, 1958: 396-402.

HAY, J. - HUTCHISON, W. M. - JACKSON, M. H. - SIIM, J. CHr . Prevalence of Toxoplasma infection in a wild rodent population from central Scotland, Ann. trop. Med. Parasit., 77, 1983: 653-654.

HEJLIČEK, K. - PROSEK, F. - TREML, F.: Isolation of Toxoplasma gondii in free-living small mammals and birds. Acta vet. Brno, 50, 1981: 233-236.

HUBNER, J. - UHL IKOVA, M.: Use of the microprecipitation method in agar gel (MPA) in the diagnostics of toxoplasmosis. 3. Correlation of MPA, complement-fixation reaction (CFT) and Sabin-Feldman's dye test (SFT) in serodiagnosis of human toxoplasmosis. J. Hyg. Epidemiol. Microbiol. Immunol., 17, 1973: 70-84.

CHHABRA, M. B. - MAHAJAN, R. C.: Prevalence of toxoplasma antibodies in dogs in Chandigarh territory, North India. Trop. and Geographical Medicine, 31, 1979: 499-502.

JIRA, J. - ROSICKY, B.: Imunodiagnostika a epidemiologie toxoplasmosy. 1. vyd. Academia Praha, 1983: $264 \mathrm{p}$.

KATSUBE, Y. - HAGIWARA, T. - IMAIZUMI, K. - HANAKI, T. - NOBUTO, K.: Reliability of the dye and modified hemaglutination tests for the latent infection of toxoplasma. Jap. J. veter. Sci., 34, 1972: 123-133.

KOUBA, K. - JIRA, J. - HUBNER, J.: Toxoplazmóza. 1. vyd. Avicenum Praha, 1974: 306 p.

KOVALEVA, Je.P. - LAVOČKIN, V. M.: 0 zaraženii toksoplazmozom pri ukusach životnymi. Z. Mikrobiol. Epidemiol. i Immunobiol., 50, 1973: 116-120.

MARTIN, M. - LETARTE, R. - HIGGINS, R.: Prevalence of toxoplasmosis in Quebec farm dogs. Veter. Rec., lol, 1977: 79-80.

OGUNRINADE, A. F.: Studies on toxoplasmosis of domestic animals in Nigeria. I. Toxoplasma antibodies in pet dogs in Ibadan area. Nigerian Medical Journal, 8, 1978: 446-448.

PETTERSEN, E. K.: Preparation of Toxoplasma gondii antigen for the complement fixation test. Acta path. microbiol. scand., 74 , 1968: $35-40$.

PETTERSEN, E. K.: Interpretace sérologických nálezú. Københaven, 1984 , personal communication.

PIEKARSKI, G. - WHITTE, H. M.: Experimentelle und histologische Studien zur Toxoplasma-Infektion der Hauskatze. Z. Parasitenkde, 36,1971 : 95-121.

POUSKA, F.: Toxoplazmóza ve světle nových objevú. Veterinárstvi, 27, 1977: 552-553.

PRESTHUS, J. - BJERKAS, I. - MOHN, S. F.: Encephalomyelitis og myositis forarsaket av toxoplasmaligende protozoo hos hund. Proceedings of the 14 th Nordic Veterinary Congress 6.-9. July 1982, Kobenhaven, pp. 165-166.

PRZYBYLKIEWICZ, Z.: Wspólczesne metody stosowane w diagnostyce toksoplazmozy. Wiad. parazyt., 18, 1972: 165-172.

PUCCINI, V. - ABBENANTE, M. G.: La toxoplasmosi del cane in provincia di Foggia: Indagine epizoologica. Atti del $34^{\circ}$ convegno nazionale. Societa Italiana dele scienze veterinárie. Sorrento, 2 - 5 October 1980,34, p. 322 . 
RASIN, K.: Toxoplasma gondii, Isospora felis - přirozená a experimentální infekce koček. Veter. Med. (Praha), 18, 1973: 593-618.

RIEMANN, H. P. - KANEKO, J. J. - HAGHIGHI, S. - BEHYMER, D. E - FRANTI, C. E. - RUPPANNER, R.: The prevalence of antibodies against Toxoplasma gondii among hospitalized (cat, dog, horse, cattle) animals and stray dogs. Can. J. comp. Med., 42, 1978: 407-413.

SACCO, T. F. - MOIRAGHI-RUGGENINI, A. - MONTE, A. DEL. - PANTANO, C. - GINANNI, C. - GRAZIONO, E.: epidemiologia della toxoplasmosi. Indagine sierologica sulla diffusione dell infezione toxoplasmica in cani e gatti dell area di Torino. Igiene Moderna, 72, 1979: 1220-1232.

SEDAGHAT, A. - ARDEHALI, S. M. - SADIGH, M. - BUXTON, M.: The prevalence of toxoplasma infection in Southern Iran. J. trop. Med. Hyg., 81, 1978: 204-207.

SIIM, J. CHr.: Antikomplementarita sér a interpretace sérologickýgh nálezú. Københaven - October (personal communication).

SEBEK, J.: Studium epizootologie toxoplazmózy a leptospirózy, výskytu mykobakterii a salmonel u služebnich psú. (Thesis), Brno, 1985: 124 p. - University of Veterinary Science.

SIBALIC, D.: Rasprostranjenost Toxoplasma gondii u člověka i raznim vrstvama životinja na nekim područjima Srbije. Acta parasit. jug., 8 , 1977: 13-18.

VOKOUN, P.: 'Dépistáž toxoplazmózy u psủ a koček ve městě. Veterináš́stuí, 32, 1982: 129-131.

WATSON; A. D. J. - FARROV, B. R. H. - MCDONALD, J. P.: Prevalence of Toxoplasma gondii antibodies in pet dogs and cats. Austral. veter. J., 58, 1982: 213-214.

ZASTERA, M. - - HÜBNER, J. - POKORNÝ, J. - SEEMAN, J. - PEYCHL, L. KOTRLIK, J. - KUBÁŚEK, M. - KOUTŚYÝ, J.: K otázce zdrojú lidské toxoplasmosy. Českoslov. Epidem. Mikrobiol. Imunobiol., 15, 1966: 340-345. 